Ann. Biol. anim. Bioch. Biophys., 1978, 18 (4), 1067-1072.

\title{
Ovarian rematuration of ablated sugpo prawn Penaeus monodon Fabricius *
}

\author{
par Jurgenne H. PRIMAVERA, E. BORLONGAN \\ Aquaculture Department \\ Southeast Asian Fisheries Development Center \\ Box 256, Iloilo City, Philippines.
}

\begin{abstract}
Summary. Spent Penaeus monodon females were tagged around one eyestalk with numbered brass tags, stocked in a concrete tank with males, and periodically examined for ovarian rematuration over a six-month period (February to August, 1977). The females were either artificially-induced (ablated spawners from concrete tanks and marine pens) or wild spawners. Most of the wild spawners were ablated after spawning; some remained unablated to serve as controls. Out of a total of 349 experimental females, 35 or 10.1 p. 100 had a second spawning and 5 or 1.4 p. 100 a third spawning; none of the 74 controls spawned subsequently. The average number of days for maturation and rematuration were : ablation to first spawning, 22.6 days ; first spawning to second spawning (for females ablated before the first spawning), 11 days ; first spawning to second spawning (for females ablated after the first spawning), 15 days; and second spawning to third spawning, 10.4 days. Fecundity of rematured spawners is comparable to that of first spawners ; there is insufficient data on hatching rate and fry survival.
\end{abstract}

\section{Introduction.}

Completion of the life cycle in captivity of the giant tiger prawn or sugpo Penaeus monodon using the eyestalk ablation method was first achieved in the Igang Sea Farming Station of the SEAFDEC Aquaculture Department (Santiago, 1977). Destruction or removal of the eyestalk in prawns and other decapod crustaceans induces ovarian maturation by eliminating the production and storage sites of the ovary-inhibiting hormone (Adiyodi and Adiyodi, 1970).

Up to 1976, most of the females spawned in the Department came from the wild ; for January to June 1976, wild spawners constituted 98 p. 100 of total supply. The successful mass production of spawners by unilateral ablation in marine prawn pens and land-based tanks has increased the proportion of ablated spawners to 84 p. 100 for the March to August, 1977 period.

* Contribution No. 17, SEAFDEC. 
To what extent spent females can remature and spawn successive broods is an important question in terms of recycling spawners in a commercially viable operation. Corollary to the rate of rematuration is the quantity and quality of fry from rematuring females in comparison to those from first spawnings.

\section{Materials and methods.}

Spent $P$. monodon females from wild (unablated) and broodstock (ablated) sources spawned in the hatchery and wet laboratory of the SEAFDEC Aquaculture Department in Tigbauan, are routinely tagged around one eyestalk with numbered brass tags (Rodriguez, 1977) for rematuration studies. The ablated females come from concrete tanks in the Tigbauan station or marine pens in the Batan station. Wild spawners are ablated after tagging ; some remain unablated to serve as controls. Spawning is verified the following day by checking the outline of the ovaries while holding the female against a bright light in a darkroom ; both partially and completely spawned females are used. Partial spawners may spawn or resorb remaining eggs in the next few days ; it is standard procedure to keep them in the spawning tank only for the first night.

This study covers the 6-month period of February to August, 1977. All females were stocked in a $4.85 \times 4.85 \times 2.80 \mathrm{~m}$ concrete tank with approximately an equal number of males. There was no bottom substrate in the tank and water depth was at least one $\mathrm{m}$. Feeding was once to twice daily salted or fresh brown mussel (Modiolus metcalfei) meat at 10 p. 100 estimated prawn body weight. Sampling for rematuration of females was done every five days during which the tank was cleaned and the water completely changed.

Rematuring females were taken to the wet laboratory for spawning and rearing of the larvae. One to three spawners were placed in one-ton fiberglass tanks with seawater of 26-29 $\mathrm{C}$ temperature and 30-34\% salinity. The tank was covered with a dark cloth or corrugated plastic and provided with two airstones. The numbers of eggs and nauplii were estimated by taking five one-l beaker samples, counting individual eggs and nauplii and computing the average number per sample multiplied by the total water volume in the tank.

\section{TABLE 1}

Number of spownings and survival in ablated and unablated P. monodon

\begin{tabular}{|c|c|c|c|c|c|c|c|}
\hline & \multicolumn{3}{|c|}{ No. of spawnings } & \multicolumn{4}{|c|}{ No. of days survival } \\
\hline & 1st & 2nd & 3 rd & Ave. & S. D. & Min. & Max. \\
\hline $\begin{array}{l}\text { Ablated before first spawn- } \\
\text { ing (pond stock) ........... } \\
\text { Ablated after first spawning }\end{array}$ & 316 & 33 & 5 & 9.2 & 6.8 & 0 & 40 \\
\hline $\begin{array}{l}\text { (wild) } \ldots \ldots \ldots \ldots \ldots \ldots \\
\text { Unablated } \ldots \ldots \ldots \ldots \ldots\end{array}$ & $\begin{array}{l}33 \\
74\end{array}$ & $\begin{array}{l}2 \\
0\end{array}$ & $\begin{array}{l}0 \\
0\end{array}$ & $\begin{array}{l}8.4 \\
7.9\end{array}$ & $\begin{array}{l}6.5 \\
6.8\end{array}$ & $\begin{array}{l}0 \\
1\end{array}$ & $\begin{array}{l}27 \\
44\end{array}$ \\
\hline Total ... & 423 & 35 & 5 & & & & \\
\hline
\end{tabular}




\section{Results.}

Of 349 experimental females, only 10.1 p. 100 had a second spawning and 1.4 p. 100 a third spawning (table 1). It takes an average of 23 days and a minimum of 12 days after ablation for a prawn with immature ovaries to mature and spawn (table 2). For

TABLE 2

Number of days between ablation and spawning and between successive spawnings of $P$. monodon

\begin{tabular}{|c|c|c|c|c|c|}
\hline & \multirow{2}{*}{$\begin{array}{l}\text { No. of } \\
\text { spawners }\end{array}$} & \multicolumn{4}{|c|}{ No. of days } \\
\hline & & Ave. & S. D. & Min. & Max. \\
\hline $\begin{array}{l}\text { Ablation to first spawning } \ldots \ldots \ldots \ldots \ldots \ldots \\
\text { First spawning to second spawning }\end{array}$ & $70 *$ & 22.6 & 6.3 & 12 & 44 \\
\hline $\begin{array}{l}\text { a) ablated before first spawning } \ldots \ldots \\
\text { b) ablated after first spawning } \ldots \ldots \ldots \\
\text { Second spawning to third spawning } \ldots \ldots\end{array}$ & $\begin{array}{c}33 \\
2 \\
5\end{array}$ & $\begin{array}{l}11.0 \\
15.0 \\
10.4\end{array}$ & - & $\begin{array}{l}5 \\
8 \\
5\end{array}$ & $\begin{array}{l}23 \\
22 \\
18\end{array}$ \\
\hline
\end{tabular}

* Exact date of ablation is known only for 70 of a total 316 females ablated before first spawning ; the remaining females were ablated in other SEAFDEC stations.

TABLE 3

Data on second spawning of ablated P. monodon

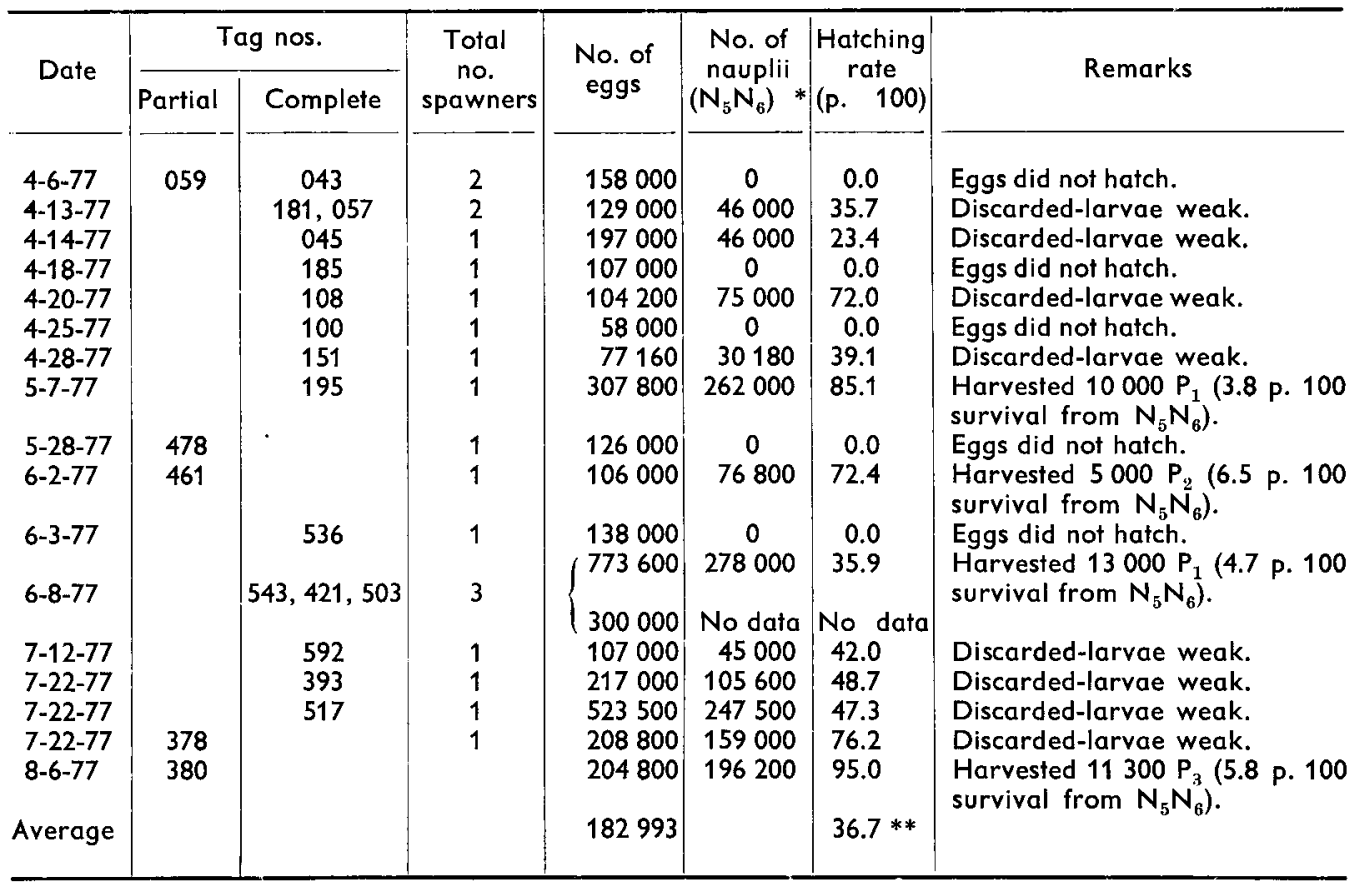

* Count was made during the fifth and sixth substages of the nauplius.

** Weighted average. 
previously ablated females, there is an average of 11 days between first and second spawnings whereas it takes 15 days for wild females ablated after the first spawning. The average between second and third spawnings is 10.4 days.

The kind of first spawning did not affect the length of time it takes for rematuration and subsequent spawning ; complete spawners $(n=24)$ took on the average 10.7 days for a second spawning as compared to 12.6 days for partial spawners $(n=11$ ) (A subsequent spawning does not include completion of earlier partial spawning.)

Second spawnings average 180000 eggs (table 3) while third spawnings average 140000 eggs (table 4), both with a hatching rate of 35 p. 100 or greater in contrast with 110000 to 120000 eggs with a hatching rate of 64 p. 100 for first spawnings from wet laboratory data. Although rematuring females show a slight increase in fecundity and a decrease in hatching rate compared to first spawnings, the small number of samples makes generalization difficult.

TABLE 4

Dafa on third spawning of ablated P. monodon

\begin{tabular}{|c|c|c|c|c|c|c|c|}
\hline \multirow{2}{*}{ Date } & \multicolumn{2}{|c|}{ Tag nos. } & \multirow{2}{*}{$\begin{array}{c}\text { Tolal } \\
\text { no. } \\
\text { spawners }\end{array}$} & \multirow{2}{*}{$\begin{array}{l}\text { No of } \\
\text { eggs }\end{array}$} & \multirow{2}{*}{$\begin{array}{c}\text { No. of } \\
\text { nauplii } \\
\left(\mathrm{N}_{5} \mathrm{~N}_{6}\right)^{*}\end{array}$} & \multirow{2}{*}{$\begin{array}{l}\text { Hatching } \\
\text { rate } \\
\text { (p. 100) }\end{array}$} & \multirow{2}{*}{ Remarks } \\
\hline & Partial & Complete & & & & & \\
\hline 5-2-77 & 100 & & 1 & - & - & - & No count. \\
\hline $\begin{array}{l}5-8-77 \\
5-30-77\end{array}$ & & $\begin{array}{l}108 \\
504\end{array}$ & $\begin{array}{l}1 \\
1\end{array}$ & $\begin{array}{r}86000 \\
130000\end{array}$ & $\begin{array}{c}0.0 \\
110000\end{array}$ & $\begin{array}{r}0.0 \\
84.6\end{array}$ & \\
\hline & & & & & & & $\begin{array}{l}(24.5 \mathrm{P} .100 \text { survival } \\
\left.\text { from } \mathrm{N}_{5} \mathrm{~N}_{6}\right) \text {. }\end{array}$ \\
\hline $\begin{array}{l}6-25-77 \\
7-27-77\end{array}$ & & $\begin{array}{l}503 \\
378\end{array}$ & $\begin{array}{l}1 \\
1\end{array}$ & $\begin{array}{l}124000 \\
220000\end{array}$ & $\begin{array}{c}0 \\
85000\end{array}$ & $\begin{array}{r}0.0 \\
38.6\end{array}$ & $\begin{array}{l}\text { Eggs did not hatch. } \\
\text { Discarded-larvae weak. }\end{array}$ \\
\hline Average & & & & 140000 & 48750 & 34.8 & \\
\hline
\end{tabular}

* Fifth and sixth substages of the nauplius.

\section{Discussion.}

To a large degree, the low rate of rematuration is due to high spawner mortality; the females survived an average of only 8 to 9 days after spawning (table 1). High mortality may be traced to poor tank conditions, mainly the build-up of excess feeds on the bottom before every water change.

Moreover, a few rematurations and spawnings may have occurred in the culture tank itself during the 4-day interim between samplings. More frequent sampling could not be undertaken because of stress on the prawns and the large size of the tank. Although no unablated wild females (controls) spawned a second time, only histological studies can definitely establish non-rematuration (this work is now in progress).

The minimum of 12 days and average of 3 weeks between ablation and spawning confirm earlier observations (Aquacop, 1977 ; Primavera ef al., 1978). The average number of days between successive spawnings from one ablated female is 11 with a 
minimum of 5 days (table 2). In comparison, 6 unilaterally ablated $P$. monodon females in Aquacop (1977) had 18 spawnings over three months for an average of one spawning per female per month with a minimum of eight days between spawnings. A unilaterally ablated $P$. orientalis female gave four spawnings with intervals of six days between spawnings (Arnstein and Beard, 1975).

In contrast, maturation data of unablated penaeids in captivity show a longer period between spawnings. Based on data up to the $F_{2}$ generation, Beard ef al. (1977) state that a $P$. merguiensis female might be expected to spawn once every 2.6 months on the average. Laubier-Bonichon and Laubier (1976) obtained 87 depositions of spawn from $60 P$. japonicus females over four months or an average of one deposition of spawn every 2.8 months under controlled photo- and thermoperiod conditions.

In the wild, $P$. monodon probably spawn more than once in their lifetime. This is suggested by a bimodal pattern of carapace length measurements of 56 and $61 \mathrm{~mm}$ on 104 gravid females caught from the wild (Motoh, pers. comm., 1977). Total length measurements of wild females of some Arabian Gulf penaeids suggest a total of five spawnings during lifetime for $P$. semisulcatus and five spawnings before attaining maximum size for Trachypenaeus granulosus (Badawi, 1975). For both species as well as Metapenaeus stebbingi, there appears to be a gap between spawnings of nearly two months, probably representing the length of time for ova to fully mature. Employing the gonad index method, Pillay and Nair (1971) conclude that the breeding season of the prawn M. affinis extends over several months of the year with distinct peaks of gonadal activity and indicate the possibility of production of successive broods of eggs by one female during a single breeding season.

\section{Conclusion.}

If the rate of rematuration is increased and the hatching rate and fry quality from subsequent spawnings improved by good nutrition, throughflow water and other better rearing conditions, rematuration of spent $P$. monodon spawners may further decrease broodstock costs.

Résumé. Des femelles Penaeus monodon matures marquées et stockées en bassins bétonnés ont été périodiquement examinées pendant une période de 6 mois (février à août 1977) afin d'identifier les rematurations ovariennes. Les femelles étaient soit des géniteurs à reproductior: artificiellement induite par ablation des pédoncules oculaires et provenant de bassins ou de cages en mer, soit des géniteurs sauvages. La plupart des géniteurs sauvages ont subi une ablation après la fraie et d'autres sans ablation oni servi de contrôle. Sur un total de 349 femelles expérimentales, 35 (soit 10 p. 100) ont présenté une seconde fraie et 5 (soit 1,4 p. 100) une troisième. Aucun des 74 témoins n'a frayé. Le nombre moyen de jours nécessaires pour la maturation ou la rematuration était de 22,6 entre ablation et première fraie, 11 entre première et deuxième fraie (cas d'ablation après la première) et 10,4 entre la deuxième et la troisième fraie. La fécondité des géniteurs à leur première maturité est comparable à celle des maturités suivantes. Les données concernant les taux d'éclosion et la survie larvaire sont insuffisantes. 


\section{References}

ADIYODI K. G., ADIYODI R. G., 1970. Endocrine control of reproduction in decapod crustacea. Biol. Rev., 45, 121-165.

AQUACOP, 1977. Observations sur la maturation ef la reproduction en captivité des crevettes Peneides en milieu tropical. Groupe de travail aquaculture, ICES, 10-13 mai 1977, Brest, France, 15 p.

ARNSTEIN D. R., BEARD T. W., 1975. Induced maturation of the prawn Penaeus orientalis Kishinouye in the laboratory by means of eyestalk removal. Aquaculture, 5, 411-412.

BADAWI H. K., 1975. On maturation and spawning in some penaeid prawns of the Arabian Gulf. Mar. Biol., 32, 1-6.

BEARD T. W., WICKINS J. R., ARNSTEIN D. R., 1977. The breeding and growth of Penaeus merguiensis de Man in laboratory recirculation systems. Aquaculture, 10, 275-289.

LAUBIER-BONICHON A., LAUBIER L., 1976. Controlled reproduction in the shrimp Penaeus japonicus. FAO techn. Conf. Aquac., May 26-June 2, 1976, Kyoto, Japan.

PILLAY K. K., NAIR N. B., 1971. The annual reproductive cycles of Uca annulipes, Portunus pelagicus and Metapenoeus affinis (Decapoda : Crustacea) from the South-west Coast of India. Mar. Biol., 2,152-166.

PRIMAVERA J. H., BORLONGAN E., POSADAS R. A., 1978. Mass production in concrete tanks of sugpo Penaeus monodon Fabricius spawners by eyestalk ablation. Fish. Res. J. Phil., 3 (in press).

RODRIGUEZ L. R., 1977. A simple method of tagging prawns. U. P. nat. appl. Sci. Bull., 28 (in press).

SANTIAGO A. C. Jr., 1977. Successful spawning of cultured Penaeus monodon Fabricius after eyestalk ablation. Aquaculture, 11, 185-196. 